\title{
A pre and post election comparison of the affirmative action policies of South African listed companies ${ }^{1}$
}

\author{
M. Shotter \\ School of Accountancy \\ University of Pretoria \\ PRETORIA
}

\author{
J.J. de Beer \\ Department of Human Resources \\ University of Pretoria \\ PRETORIA
}

\begin{abstract}
A pre and post election comparison of the affirmative action policies of South $\Lambda$ frican listed companies

Affirmative action can be described as the enforced empowerment and occupational advancement of historically disadvantaged groups. These disadvantaged groups can only be empowered and occupationally advanced once opportunities for occupational advancement, personal development and an improved quality of life have been created. In this article the influence of the first democratic election of 27 April 1994 on affirmative action policies of the South African companies listed on the Johannesburg Stock Exchange is investigated. Subsequent to the election a marked increase in the percentage of listed companies applying affirmative action policies has been observed in respect of occupational advancement and personal development. An increase in the quality of life benefits and facilities made available to all employees is not, however, always evident.
\end{abstract}

Key words

Affirmative action, historically disadvantaged employees

\section{Background}

Racism and various other factors created social and economic inequalities in the South African society (Fendale, 1993; Rist, 1993:7-12; Führ, 1993). According to Justice Harry Blackman (quoted in Mphelo et al., 1993) "to get beyond racism we must take account of race. There is no other way. And in order to treat some persons equally we must treat them differently".

Our thanks and appreciation to our colleagues of the University of Prctoria for their assistance and to the Centre for Science Development for financial support. Opinions given in this report or conclusions reached are those of the authors and should not necessarily be attributed to the Centre for Science Development. Originally presented as a paper at the ANZAM conference, Wollongong. Australia, December 1996 
A pre and post election comparison of the affirmative action policies of SA listed companies

An intervention, which is generally referred to as affirmative action, has been suggested as a remedy for the harm caused by racism in the South African society.

Wingrove (1994:5) describes affirmative action as "the enforced empowerment and occupational advancement of historically disadvantaged minority groups", whilst Rist (1993:20) suggests that it implies the taking of a positive step to remove the backlog caused by discrimination. The Black Management Forum (1993:4) defines affirmative action as "a planned and positive process and strategy aimed at transforming socio-economic environments which have excluded individuals from (dis)advantaged groups, in order for such disadvantaged individuals to gain access to opportunities, including developmental opportunities, based on their suitability".

Smit (1992:32) sees affirmative action as programmes affirming the positive countering of discrimination in order to ensure equal treatment to all. Olen and Barry (quoted in Rist, 1993:20) describes it as a process "to rectify the consequences of discrimination that have resulted in the unfair treatment of some individuals or groups to enable these persons to compete on par with their colleagues". For the purpose of this article the definition according to Wingrove (1994:5), namely "enforced empowennent and occupational advancement of historically disadvantaged groups" will be subscribed to.

\section{The scope of this article}

South Africa's first democratic election resulted in tremendous change in the political, social and economic field. This article investigates the effect of the first democratic election of 27 April 1994 on the affirmative action policies of the listed companies of South Africa.

The first part of the article considers the justification of affirmative action on ethical grounds and gives an overview of the pre and post election scenarios in the South African business community, with specific reference to the implementation of affirmative action. The second part of the article compares affirmative action policies, as observed in surveys prior to and subsequent to the above election.

\section{The ethical considerations of affirmative action}

Unless the question of whether affirmative action is ethically justified, that is "inherently right", is answered positively, any efforts to successfully implement affirmative action programmes will be met with resistance.

Kruger and De Klerk's article (1995:401-426) in which the ethical grounds for affirmative action are investigated, come to the conclusion that affirmative action 
can be justified on ethical grounds in the South African situation. Their conclusion is based on testing the principles of affirmative action against a number of ethical theories, including compensatory justice, fairness, distribution on the basis of proportional equality of merit, equality of need, and the theory of personal freedom.

Shubane (1995:23) disagrees and states that the practice of affirmative action is fundamentally wrong, because it judges people according to race and not on the content of their character. $\mathrm{H} \approx$ argues that one standard should be set by which all people are judged. In tesponse to his argument Van der Merwe (1994:3) focuses on the need for compensation after years of discrimination in South Africa A.ccording to him it will be unfair to expect the disadvantaged to compete on equal grounds with those who benefited from the discriminatory system.

Smit (1992:32) sees affirmative action as a means to ensure equal treatment of all He agrees that there should be some kind of restitution, but suggests that it should be in the form of compensation, education and training programmes. According to him recruitment, selection, appointment and promotion should only be based on merit. Boatright (1993:234), however, is of the opinion that the termination of discrimination and the implementation of educational type programmes will not be enough. Equal rights will not ensure equal opportunities and equal treatment (Klug quoted in Rist, 1993:20). Mokhobo (quoted in Luhabe, 1993) remarks in this regard: "there is nothing as unequal as the equal treatment of unequals".

Shubane (1995:15) furthermore states that affirmative action should concentrate on the disadvantaged according to their needs and not according to colour. He reasons that if no attempt is made to distinguish between those who deserve to benefit from affirnative action in terms of their needs, the danger exists that affirmative action can bolster the position of a relatively privileged stratum of blacks, since they are the ones who are best equipped to claim benefits and to use the opportunities currently created by these policies. Klug (quoted in Rist, 1993:25) disagrees and argues that only three requirements should be met to identify a person/group for the benefits of affirmative action, namely: the group should be a social group, the group should have been subjected to continuous oppression and the political rights of the group should have been seriously limited. The black population of South Africa qualifies in all three respects

Van der Merwe (1994:25) reminds us that any ethical issue is first and foremost an attitude issue. People can love and encourage one another in spite of corrupt systems, and can break each other down within perfect systems. People should be seen in their totality; all their needs, abilities, opportunities, ideals and community structures should be taken into account when formulating an affirmative action programme. For the purpose of this article, it is accepted that affirmative action can be justified on ethical grounds. 


\section{The implementation of affirmative action}

\subsection{The roles of the government and black trade unions in the implementation of affirmative action}

Prior to the election the affirmative action process was driven by black conscious movements in alliance with the African National Congress (ANC), which came to power in 1994 (Rosmarin, 1994). The black unions also played an important but subservient role to the ANC in the implementation of affirmative action in organizations.

The pre election political manifesto of the ANC visualised affirmative action within the broader structure of a socialist and centralised reconstruction and development policy. Black unions supported this broader approach because it emphasised material and educational empowerment of the masses of historically disadvantaged people. These unions were not very supportive of the companies' own initiatives which usually led to the advancement of only a select elitist minority of high level black employees (Wingrove, 1994:34, 70).

Subsequent to the election, the ANC-dominated government of national unity pursued its national policy of reconstruction and development (RDP) but gradually moved towards decentralising the RDP and legislating the enforceinent of affirmative action in the private sector. The unions which were already putting pressure on management to participate in social investment programmes regarding employee training, matemity leave, day-care, etc. became more actively involved. They moved from relatively passive support for the Govenument's affirmative action policy towards being more actively involved in the planning and implementation of affirmative action policies in companies. They also took on the role of "watch-dogs" of Government regarding the progress made by companies (Charlton \& Van Niekerk, 1994:xv-xxii).

It is apparent that the Government of the day and the unions exerted pressure on companies to implement affirmative action and that this pressure intensified after the 1994 elections.

\subsection{The holistic approach to the implementation of affirmative action}

During the early 1980s a holistic approach emerged to achieve empowerment and the advancement of historically disadvantaged groups. Project Free Enterprise (1985) identified the important effect of home and school environment on the work performance and development of employees. In addition, there was a growing awareness of company participation in the remedial education of their employees, Smit (1992:52-53) and Luhabe (1993) concur. In order to achieve the objectives of affirmative action, issues like housing, education, health and small business development should inter alia be addressed 
For the purpose of this article, the holistic approach to affirmative action is emphasised, namely that historically disadvantaged groups can only be empowered and occupationally advanced once opportunities for the following have been created: occupational advancement, personal development and an improved quality of life.

Although these disadvantaged groups include women, black people, the aged and the physically disabled, the focus is currently on the empowerment of disadvantaged black employees in a South African context, and this will also be the focus of this article.

\subsubsection{Occupational advancement}

There are various approaches to be followed in order to rectify the effect of discriminatory policies on occupational advancement.

One approach is that of passive non-discrimination in terms of which all decisions affecting employees are done in a non-discriminatory fashion. This approach addresses the present and the future but fails to rectify the unfair decisions of the past (Frederick, Davis \& Post, 1988:306).

Another approach suggested by Frederick et al. (1988:306) is what they describe as occupational advancement by means of affirmative action. They distinguish between the following three categories:

* Recruitment, appointment and promotion without an emphasis on underprivileged candidates.

* Recruitment, appointment and promotion with an emphasis on underprivileged candidates.

* Recruitment, appointment and promotion in tenns of a quota system for underprivileged candidates.

In terms of the first category companies make every effort to recruit historically disadvantaged employees but continue to base appointment and promotion decisions on merit. The approach followed in the second category is to recruit, appoint and promote employees with an emphasis on the historically disadvantaged employees. The third category is establishing employment quotas, implying that a specific quota of the total number of employees should be represented by historically disadvantaged employees. According to Brimelow and Spencer (1993:80-100) a quota system will cause harm to not only the company and the community but also to the historically disadvantaged employee. 
A pre and post election comparison of the affirmative action policies of SA listed companies

Prior to the election, most companies followed the passive non-discrimination approach, as described above by Frederick et al. (1988:306).

Subsequent to the election Mkhwanazi (1994:7) argued that even when all legal barriers were removed and black employees reached the same skills level as whites by means of extensive development programmes, they were usually not promoted due to deeply rooted informal racial discrimination practices. Mkhwanazi (1994:11) therefore suggests that in order to ensure a more just representation of black employees in skilled and management positions, the occupational advancement of black employees should be implemented more purposefully and more forcefully.

After the election, the South African Chamber of Business (1995:2) observed that some managers adopted a short term preferential policy, in terms of which emphasis is placed on the recruitment and promotion of black employees in preference to white employees of equal potential and ability, for a limited period of time. According to Rosmarin (1994) preferential treatment is given to black employees in respect of recruitment, development and promotion. It is envisaged that preferential treatment of certain groups will be implemented for a certain period of time or as long as is required to rectify the imbalances of the past (Rosmarin, 1994). Smit (1992:33-34) agrees that affirmative action programmes should be of a temporary nature. The Black Management Forum (quoted in Rist, 1993:35) acknowledges that a permanent strategy of affirmative action can be classified as (reversed) discrimination.

Another policy adopted after the election can be referred to as the short term output-based policy (South African Chamber of Business, 1995:2). This policy implies rigid timetables and fixed quotas for the appointment of black employees in all job categories. These quotas are set to closely represent the population composition of the region or community in which the company operates. The quotas are set with the primary objective of achieving the empowerment of a given number of employees within a set time limit (South African Chamber of Business, 1995).

Some managers resist the pre-occupation with quantifiable results and prefer setting constructively achievable timetables as an incentive for progress. They reason that pre-occupation with the quantifiable results may have a detrimental effect on the work standards and efficiency of the workforce (Wingrove, 1994:33).

In order to meet the stipulated quotas, management makes every effort to identify and develop historically disadvantaged employees with management potential. The most popular approach is to identify development needs in all job levels and implement accelerated development programmes. Certain companies recruit 
developed individuals and are prepared to pay for developed skills. The more pro-active companies identify school children with high potential and heavily invest in their educational development or simultaneously embark on all of these avenues (Wingrove, 1994:93).

This distinctive characteristic of the occupational advancement approach followed after the election and implies enforced employment and the rapid development of black employees even if it means short or medium-term reversed discrimination against some white employees (Wingrove, 1994:162).

\subsubsection{Personal development}

During the early 1980 s management became aware of the difference in skills levels between black and white employees. Thopane (1986:52-58) later referred to this difference as the skills gap. He suggested that this gap, as well as the limited exposure of black employees to the modern company work ethic and the lack of black managerial role models, contributed to the slow progress in black employee advancement.

To resolve these problems human resources practitioners proposed that companies should directly intervene in the employee's basic process of development. Companies introduced special development programmes to redress education and role-model backlogs (Moerdyk, 1986). The focus of these special programmes was not only to provide formal but also to provide informal education and support. Extended support systems were introduced to encourage the black employee in his/her adjustment in skilled and managerial positions. Mentor systems were adopted in terms of which senior employees were appointed to act as mentors and role models for the developing employee (Moerdyk, 1986).

According to Project Free Enterprise (1985) and Charoux (1986:55-56) the development programmes included training in literacy, numeracy and advanced reading skills, Western etiquette, study techniques, leadership and managerial skills, the principles of economics, life awareness and problem solving techniques.

Prior to the election, companies were reluctant to set clear time limits and objectives on the advancement of the black employees but accepted these programmes as long term investments (Charoux, 1986:4). Due to the fact that it was difficult to measure progress objectively, many companies refrained from measuring the success of their black advancement programmes (Human \& Hofmeyer, 1985:15-17).

Subsequent to the election, affirmative action became a strategic business issue which nowadays has an impact on competitiveness and long-term business 
A pre and post election comparison of the affirmative action policies of SA listed companies

viability (Bornman, 1994). Where affirmative action policies were pursued to a limited extent prior to the election, these policies were generally and vigorously executed.

Where, prior to the election, companies preferred to target only certain high potential employees for accelerated personal development, subsequent to the election, development programmes were extended to a wider base of historically disadvantaged employees (Charlton \& Van Niekerk, 1994:98). This shift in focus can partly be ascribed to the pressure exerted by Black Consciousness movements and labour unions which were of the opinion that all the black employees were marginalised and ought to be included in personal development programmes.

\subsubsection{Improved quality of life}

During the early 1980 s, the South African business community became aware of the importance of their involvement in improving the welfare of their historically disadvantaged employees and many companies embarked on social responsibility projects (Nel, 1992:26-28). These projects were characterised by an absence of employee participation in the decision-making process regarding projects as well as a preference towards projects which would directly lead to increased efficiency and economic gain for the company. Examples of these projects inter alia include support for employees' transport and drug dependency rehabilitation programmes. The company involvement in the community needs outside the organisation was limited (Nel, 1992:28).

During the late 1980s and the early 1990s a change in attitude occurred concerning the business community's role in society. This attitude was reflected by the replacement of the tern social responsibility by the phrase social investment. The contribution of the company to improving the quality of life of the broader community was now also seen as an investment in the future (Bornman, 1992; Nel, 1992:26-28).

Subsequent to the election, the social investment approach gained popularity as a management philosophy and it became an integral part of the strategy as a micaris for future economic survival. Nowadays a substantial amount of company profit is annually budgeted for social investment programmes and managed within the strategic mission of the company (Coln, 1994).

\section{Empirical research}

\subsection{Methodology}

In order to compare the policy on affirmative action of South Africa's listed companies for the periods before and after the election of 27 April 1994, the 
companies were surveyed by means of questionnaires. A comparative research design (Chadwick et al., 1984:52) was followed and the surveys were carried out during August 1993 to January 1994 (Shotter, 1994:80) and April to May 1995, respectively.

These surveys were carried out on an anonymous basis and were circulated twice during the respective periods. The questionnaires were addressed to the senior officials concerned with employees.

\subsection{Population and sampling}

The companies listed on the Johannesburg Stock Exchange were selected as the target group due to the fact that these companies exert a strong influence on the direction in which affirmative action policy develops in South Africa. A nonprobability sampling method, namely judgmental sampling, was followed.

The populations, in respect of both surveys, were defined in consultation with the Bureau for Financial Analysis at the University of Pretoria and with reference to the Johannesburg Stock Exchange handbook. The populations of the two surveys are summarised and compared below.

The pre election population consisted of 419 companies listed on the Johannesburg Stock Exchange. The number of companies which responded amounted to 113 , resulting in a response rate of $26,97 \%$.

The post election population consisted of 542 companies listed on the Johannesburg Stock Exchange. The number of companies which responded amounted to 122 , resulting in a response rate of $22,5 \%$.

As can be seen from table 1 the pre election population excluded pyramid companies (60 companies) as well as financial holding companies, property holding companies and cash shells (139 companies). Prior to the election these companies were excluded due to the fact that they were deemed to be nonoperating companies with a less significant number of employees, and therefore had less established affirnative action policies. Subsequent to the election these companies were, however, included in the population. The possible influence of this difference in the population should be limited but should, however, be borne in mind when the results are compared.

The extent of representation of the whole population can be judged according to the distribution among the different sectors of the Stock Exchange. 
Table 1: Comparison of the pre and post election populations

\begin{tabular}{|c|c|c|}
\hline & $\begin{array}{l}\text { Pre } \\
\text { election }\end{array}$ & $\begin{array}{l}\text { Post } \\
\text { election }\end{array}$ \\
\hline $\begin{array}{l}\text { Total population according to the JSE Handbook } \\
\text { - February } 1993 \\
\text { - August } 1994\end{array}$ & 679 & 616 \\
\hline $\begin{array}{l}\text { Companies which do not publish financial } \\
\text { statements - excluded by the Bureau of Financial } \\
\text { Analysis from their population }\end{array}$ & - & (3) \\
\hline Pyramid companies & $(60)$ & - \\
\hline $\begin{array}{l}\text { Companies that indicated that it is against their } \\
\text { policy to participate in surveys }\end{array}$ & (9) & (15) \\
\hline Foreign companies & (18) & (23) \\
\hline $\begin{array}{l}\text { Companies which became delisted between } \\
\text { - February } 1993 \text { and August } 1993 \\
\text { - August } 1994 \text { and April } 1995\end{array}$ & (26) & $(35)$ \\
\hline $\begin{array}{l}\text { Companies of which no shares were traded during } \\
\text { the period January and June } 1993\end{array}$ & (8) & - \\
\hline New listings between August 1994 and April 1995 & - & 2 \\
\hline \multirow[t]{2}{*}{$\begin{array}{l}\text { Financial holding companies, property holding } \\
\text { companies and cash shells }\end{array}$} & (139) & \\
\hline & 419 & 542 \\
\hline
\end{tabular}


Table 2: Pre election survey - representation of the sectors of the Johannesburg Stock Exchange

\begin{tabular}{|l|c|l|l|l|}
\hline Sector & $\begin{array}{l}\text { Mining, Gold, } \\
\text { Metal \& } \\
\text { Minerals }\end{array}$ & Financial & Industrial & Total \\
\hline $\begin{array}{l}\text { Number of companies } \\
\text { in the population }\end{array}$ & 77 & 90 & 252 & 419 \\
\hline $\begin{array}{l}\text { Number of companies } \\
\text { response per sector }\end{array}$ & 12 & 16 & 83 & $111^{*}$ \\
\hline$\%$ Response per sector & $15,58 \%$ & $17,78 \%$ & $32,94 \%$ & $26,97 \%$ \\
\hline
\end{tabular}

* Two of the respondents did not specify their respective sectors.

Table 3: Post election survey - representation of the sectors of the Johannesburg Stock Exchange

\begin{tabular}{|l|c|c|c|c|}
\hline Sector & $\begin{array}{l}\text { Mining, Gold, } \\
\text { Metal \& } \\
\text { Minerals }\end{array}$ & Financial & Industrial & Total \\
\hline $\begin{array}{l}\text { Number of companies } \\
\text { in the population }\end{array}$ & 85 & 130 & 342 & 557 \\
\hline $\begin{array}{l}\text { Number of companies } \\
\text { response per sector }\end{array}$ & 22 & 17 & 75 & $114^{*}$ \\
\hline$\%$ Response per sector & $26 \%$ & $13 \%$ & $22 \%$ & $20 \%$ \\
\hline
\end{tabular}

*Eight of the respondents did not specify their respective sectors.

The gold, mining and metals, and minerals sectors were combined into one sector for the purpose of analysing the results. The percentage representation of the three combined sectors in the population are, in both surveys, adequately reflected in the percentage representation in the response received and can therefore be accepted as representative of the population as a whole. 
A pre and post election comparison of the affirmative action policies of SA listed companies

\subsection{Compilation of the questionnaire}

The questionnaire was designed in order to assess the extent to which listed companies implement affinnative action policies regarding opportunities for occupational advancement, personal development and an improved quality of life for their historically disadvantaged employees. The questions were presented on a nominal level and were standardised in order to ensure clarity and relevance (Shotter, 1994:77). The specific aspects included in the questionnaire are listed below:

\section{- Occupational advancement}

* Policies regarding recruitment, appointment and promotion.

- Personal development

* Literacy education

* Numeracy education

- Improved quality of life

* Paternity leave

* Housing benefits

* Rehabilitation programmes for employees with alcohol or drug dependency problems

* Transport to and from home

* Day-care facilities for children of employees

It was not possible to test all factors affecting the success rate of a company in its effort to empower and advance historically disadvantaged employees. The above factors should, however, give an indication of the commitment of a company in this regard.

\section{Results and discussion}

The results of the survey are described and discussed in three categories of affirmative action namely, opportunities for occupational advancement, personal development and an improved quality of life

The statistical significance is evaluated on tests of proportion. A Z-score $>1.645$ indicates a meaningful increase in affirmative action policies after the election 


\subsection{Occupational advancement}

The following three tables compare the recruitment, appointment and promotion policy of the listed companies in South Africa, as observed prior to, and subsequent to the election.

Table 4: Recruitment with the emphasis on underprivileged candidates

\begin{tabular}{|c|c|}
\hline & Total response \\
\hline Pre election & $26 \%$ \\
\hline Post election & $51 \%$ \\
\hline
\end{tabular}

Z-score $=3.90461$

Table 5: Appointment with the emphasis on underprivileged candidates

\begin{tabular}{|l|c|}
\hline & Total response \\
\hline Pre election & $27 \%$ \\
\hline Post election & $51 \%$ \\
\hline
\end{tabular}

Z-score $=3.75457$

Table 6: Promotion according to a quota system requiring that a certain percentage of all levels of employees be represented by underprivileged employees

\begin{tabular}{|l|c|}
\hline & Total response \\
\hline Pre election & $2 \%$ \\
\hline Post election & $9 \%$ \\
\hline
\end{tabular}

Z-score $=2.41072$

The null hypotheses assume no increase in the post election emphasis placed on underprivileged candidates, in respect of recruitment, appointment or promotion. Based on the Z-scores the null hypotheses can be rejected. After the election an increase in emphasis with regard to the recruitment, appointment and promotion of underprivileged candidates can be discened. 
It seems as if a short term preferential policy, in terms of which emphasis is placed on the recruitment and appointment of underprivileged employees, in preference to privileged employees of equal potential and ability, has been adopted by the majority of the South African listed companies.

In addition, the increase in promotion according to a quota system seems to indicate that there has been an increase in the percentage of listed companies which have adopted a short-term output-based policy which implies an adoption of rigid timetables and fixed quotas for the appointment of black employees in all job categories. This policy has as yet, however, only been adopted by a small minority of listed companies.

\subsection{Personal development}

In a comparison of the pre and post election personal development programmes the following percentages of the respondents indicated that they make literacy education and numeracy education available to all employees.

Table 7: Personal development programmes

\begin{tabular}{|l|c|c|}
\hline & $\begin{array}{c}\text { Pre election } \\
\text { (percentage } \\
\text { respondents) }\end{array}$ & $\begin{array}{c}\text { Post election } \\
\text { (percentage } \\
\text { respondents) }\end{array}$ \\
\hline $\begin{array}{l}\text { Literacy } \\
\text { education }\end{array}$ & 32 & 59 \\
\hline $\begin{array}{l}\text { Numeracy } \\
\text { education }\end{array}$ & 21 & 51 \\
\hline
\end{tabular}

The null hypotheses indicate no post election increase in the percentage of companies making literacy and numeracy education available to all employees. Based on the Z-scores of 4,17385 and 4,85634 the null hypotheses can be rejected. Therefore, post election increase in the percentage of companies making literacy and numeracy education available to all employees seems te be apparent.

Where the implementation of personal development programmes were pursued to a limited extent prior to the election, these programmes now seem to be made available to all employees of the majority of the listed companies of South Africa. 


\subsection{Improved quality of life}

In a pre and post election comparison, the following percentages of respondents indicated that certain benefits or facilities were made available to all employees, in order to improve their quality of life.

Table 8: Quality of life benefits and facilities

\begin{tabular}{|l|c|c|c|}
\hline & $\begin{array}{l}\text { Pre } \\
\text { election } \\
\text { (per- } \\
\text { centage } \\
\text { respon- } \\
\text { dents) }\end{array}$ & $\begin{array}{l}\text { Post } \\
\text { election } \\
\text { (per- } \\
\text { centage } \\
\text { respon- } \\
\text { dents) }\end{array}$ & Z-score \\
\hline Housing benefits & 43 & 53 & 1.51963 \\
\hline $\begin{array}{l}\text { Rehabilitation programmes for em- } \\
\text { ployees with alcohol or drug de- } \\
\text { pendency problems }\end{array}$ & 54 & 64 & 1.38948 \\
\hline Transport to and from home & 17 & 21 & 0.69732 \\
\hline Paternity leave & 32 & 36 & 0.55168 \\
\hline $\begin{array}{l}\text { Day-care facilities for children of } \\
\text { employees }\end{array}$ & 13 & 10 & $(0.652496)$ \\
\hline
\end{tabular}

The null hypotheses indicate no post election increase in the percentage of companies making quality of life benefits and facilities available to all employees. Based on the Z-scores of all the above indicators the null hypotheses can not be rejected.

It seems as if no meaningful increase exists in respect of any of the benefits and facilities made available to all employees in order to improve their quality of life.

The above comparison does not indicate an increased commitment by the listed South African companies to improve the quality of life of their historically disadvantaged employees in the period after the election of 27 April 1994.

\section{Conclusions}

From the results of this research it can be concluded that after the 1994-election there has been a general and marked increase in the percentage of listed 
A pre and post election comparison of the affirmative action policies of SA listed companies companies applying affirmative action policies related to occupational advancement and personal development. There has, however, been no meaningful improvement in the percentage of quality of life benefits and facilities made available to all employees.

These results also seem to indicate a greater acceptance of the fact that affirmative action is currently ethically justified in the South African situation.

The fact that less progress was made with policies regarding the improvement of the quality of life benefits of employees might indicate that companies still do not see employees in their totality, with all their needs, abilities, opportunities, ideals and community structures, when formulating affirmative action programmes. Another reason might be that companies were of the opinion that they had already made substantial contributions towards improving their employees' quality of life prior to the election. In the light of pending legislation, companies could also have the view that the most serious discrepancies were in the fields of occupational advancement and training - hence their inclination to emphasise occupational advancement and personal development programmes.

The first democratic general election of 27 April 1994 resulted in tremendous change in the political, economical and social fields. These changes provided the impetus for management to commit themselves to implement affirmative action effectively and to encourage companies which have not yet implemented affirmative action to start doing so as soon as possible.

\section{Bibliography}

BLACK MANAGEMENT FORUM. 1993. The Black Management Forum: Affirmative Action Blueprint. Johannesburg. (Chairman: L M Ndlovu.)

BOATRIGHT, J R. 1993. Ethics and the Conduct of Business. New Jersey : Prentice-Hall

BORNMAN, C. 1992. Implementing Social Investment in the Organization. Unpublished article, Department of Human Resources Management, University of Pretoria.

BORNMAN, C. 1994 Social Involvement. Unpublished lecture, Department of Human Resources Management, University of Pretoria

BRIMELOW, P S. \& SPENCER, L. 1993. When Quotas Replace Merit, Everybody Suffers. Forbes :80-102, February 15.

CHADWICK, B.A., BAHR, H.M. \& ALBRECHT, S.L 1984. Social Science Research Methods. Englewood Cliffs, New Jersey: Prentice Hall Incorporated

CHARLTON, G.D. \& VAN NIEKERK, W. 1994. Affirming Action - beyond 1994 Johannesburg: Juta

CHAROUX, J.A.E. 1986. The Integration of the Black Manager. Johannesburg Juta.

COHN, H 1994 How Responsible Organisations See Their Role in Social Involvement Midrand : AIC Conferences, August

FERNDALE, U. 1993 A Broad Brush Approach to Affirmative Action. (InI Institute of Personnel Management ed Equity vs Equality - The Affirmative Action Debate. Braamfontein : Institute of Personnel Management p 1-3) 
M. Shorter \& J... de Beer

FREDERICK, W C , DAVIS, K \& POST, JE 1988 Business and Society: Corporate Strategy, Public Policy \& Ethics. New York : McGraw Hill

FUHR, I 1993. Managing Diversity. (In Institute of Personnel Management ed Equity vs Equality - The Affirmative Action Debate Braamfontein : Institute of Personnel Management p 42-45.)

HUMAN, L. \& HOFMEYER, K 1985. Black Managers in South African Organizations Kaapstad : Juta

KRUGER, S. \& DE KLERK, G.J. 1995 Regstellende aksie: 'n etiese perspektief. Koers, 60(3) $401-426$

LUHABE, W 1993 Affirmative Action: Creating the Reality. (In Institute of Personnel Management ed. Equity vs Equality - The Affirmative Action Debate Bramfontein Institute of Personnel Management. p. 8-11.)

MOERDYK, A.P. 1986. Evaluating the Effectiveness of Bridging Education Programmes Unpublished paper. Pretoria, Sielkunde Vereniging van Suid-Afrika.

MKHWANAZI, D. 1994. Financial Institutions and Black Economic Empowerment. Human Resources Management, 10(3):7-11.

MPHELO, C., GREALY, P. \& TROLLIP, T. 1993. Discrimination and the New South Africa. (In Institute of Personnel Management ed. Equity vs Equality - The Affirmative Action Debate. Braamfontein : Institute of Personnel Management. p. 70-75).

NEL, B. 1992. Social Investment - Recent Trends. People Dymamics: 26-28, July

PROJECT FREE ENTERPRISE, 1985. Free Enterprise in South Africa: Final Report Pretoria : School of Business Leadership, UNISA.

RIST, A.M. 1993. Die etiek van regstellende aksie. Johannesburg : Randse Afrikaanse Universiteit. (Ongepubliseerde skripsie.)

ROSMARIN, K. 1994. Orientation to Affirmative Action. Unpublished lecture, Department of Human Resources Management, University of Pretoria.

SHOTTER, M. 1994. Die sosiale verantwoordelikheid van genoteerde sake-ondernemings in die Republiek van Suid-Afrika. Pretoria : Universiteit van Pretoria. (M.Commverhandeling.)

SHUBANE, K. 1995. Wrong Cure: Affirmative Action and South Africa's Search for Equality. Policy: Isswes \& Actors, 8(4):1-25, February.

SMIT, K. 1992. Swart perspektiewe op "affirmative action". Koers, 57(1):31-57.

SOUTH AFRICAN CHAMBER OF BUSINESS (SACOB). 1995. A SACOB policy on Affirmative Action. Unpublished policy document, SACOB : Johannesburg.

TLHOPANE, S. 1986. Black Advancement Strategies Ussalep verslag: 52-58.

VAN DER MERWE, J.C. 1994. Regstellende aksie: prinsipiële riglyne. Instituut vir Reformatoriese Studie, PU vir CHO : Potchefstroom. Reeks F1 No. 313.

WINGROVE, T. 1994. Affirmative Action. Johannesburg : Knowledge Resources. 